\title{
Social Determinants of Health in the lives of urinary catheter users
}

\author{
Determinantes Sociais de Saúde na vida de usuários de cateterismo urinário \\ Determinantes Sociales de Salud en la vida de usuarios de cateterismo urinario
}

\section{Beatriz Maria Jorge', Laís Fumincelli', Valtuir Duarte de Souza-Junior', Rodrigo Guimarães dos Santos Almeida', Alessandra Mazzo', Carla Aparecida Arena Ventura', Isabel Amélia Costa Mendes' \\ ' Universidade de São Paulo, Ribeirão Preto College of Nursing. Ribeirão Preto, São Paulo, Brazil.}

\author{
How to cite this article:
}

Jorge BM, Fumincelli L, Souza-Junior VD, Almeida RGS, Mazzo A, Ventura CAA, et al. Social Determinants of Health in the lives of urinary catheter users. Rev Bras Enferm [Internet]. 2018;71(4):1928-33. DOI: http://dx.doi.org/10.1590/0034-7167-2017-0282

\section{ABSTRACT}

Objective: To identify the influence of social determinants of health on the life conditions of patients who use intermittent urinary catheters. Method: This was a descriptive study conducted in a rehabilitation center with 243 neurogenic bladder patients who used clear intermittent urinary catheters. The study was carried out between March 2012 and October 2015, using interviews based on semi-structured instruments, and data analysis using descriptive statistics. Results: Most of the patients were men, between 16 and 64 years old, single, with an elementary education level, and a monthly household income of 2 to 3 minimum wages. The results show that the social determinants of health were related to socioeconomic, demographic, and health factors. Conclusion: The findings indicate a complex relationship between social determinants of health and the life conditions of patients who use clean intermittent urinary catheters, presenting greater vulnerability related to some aspects of health conditions.

Descriptors: Social Determinants of Health; Right to Health; Social Conditions; Intermittent Urethral Catheterization; Neurogenic Urinary Bladder.

\section{RESUMO}

Objetivo: Identificar a influência de fatores dos determinantes sociais de saúde nas condições de vida de pacientes usuários de cateterismo urinário intermitente. Método: Pesquisa descritiva realizada em um Centro de Reabilitação com 243 pacientes com bexiga neurogênica, usuários de cateterismo urinário intermitente limpo. O período do estudo foi de março/2012 a outubro/2015, utilizando-se entrevista com apoio de um instrumento semiestruturado e análise por estatística descritiva. Resultados: A maioria dos pacientes era do gênero masculino, idade entre 16 e 64 anos, solteiros, com ensino fundamental e renda familiar mensal de 2 a 3 salários mínimos. Os determinantes sociais de saúde encontrados foram relacionados aos aspectos socioeconômicos, demográficos e condições de saúde. Conclusão: Os achados assinalam para uma complexa relação entre os determinantes sociais de saúde e as condições de vida desses pacientes usuários de cateterismo urinário intermitente limpo, apresentando uma vulnerabilidade com relação a alguns aspectos das condições de saúde.

Descritores: Determinantes Sociais de Saúde; Direito à Saúde; Condições Sociais; Cateterismo Uretral Intermitente; Bexiga Urinária Neurogênica.

\section{RESUMEN}

Objetivo: Identificar la influencia de factores de los determinantes sociales de salud en las condiciones de vida de pacientes usuarios de cateterismo urinario intermitente. Método: Investigación descriptiva realizada en centro de Rehabilitación. Participaron 243 pacientes con vejiga neurogénica, usuarios de cateterismo urinario intermitente limpio. Estudio realizado entre marzo de 2012 y octubre de 2015, aplicando entrevista apoyada por instrumento semiestructurado, y análisis por estadística descriptiva. Resultados: La mayoría de los pacientes era de sexo masculino, edad entre 16 y 64 años, solteros, con enseñanza primaria e ingresos familiares entre 2 y 3 salarios mínimos. Los determinantes sociales de salud encontrados estuvieron relacionados a aspectos socioeconómicos, demográficos y condiciones de salud. Conclusión: Los hallazgos señalan una compleja relación entre 
los determinantes sociales de salud y las condiciones de vida de estos pacientes usuarios de cateterismo urinario intermitente limpio, presentando vulnerabilidad en relación a algunos aspectos de las condiciones de salud.

Descriptores: Determinantes Sociales de la Salud; Derecho a la Salud; Cateterismo Uretral Intermitente; Vejiga Urinaria Neurogénica.

\section{CORRESPONDING AUTHORＩsabel Amélia Costa MendesＥ-mail: iamendes@usp.br}

\section{INTRODUCTION}

The World Health Organization (WHO) defines health as physical, mental and social well-being, and not only as the absence of illness, which encompasses multiple conditions that decisively influence this process ${ }^{(1)}$. Among these conditions, social, economic, political, cultural and environmental health factors as a group are denominated social determinants of health $(\mathrm{SDH})$, which establish mutually determining relationships among themselves that impact the lives of individuals and groups. This includes characteristics of daily life, such as social class, education level, security, diet, housing, and access to health services ${ }^{(2-4)}$.

In Brazil, the National Commission on Social Determinants of Health (CNDSS) is based on the WHO framework of health and the main constitutional principles set forth in Article 196 of the Federal Constitution, which posits health as "[...] a right of all and a duty of the State and shall be guaranteed by means of social and economic policies aimed at reducing the risk of illness and other hazards and at the universal and equal access to actions and services for its promotion, protection and recovery ${ }^{\prime \prime(5-6)}$.

Regarding $\mathrm{SDH}$, it is important that policies and actions aim to minimize the effects of differences that result from social and economic disparity between individuals or groups. SDH influence the health-illness process differently in different social groups, according to their characteristics ${ }^{(3-4)}$. The location where individuals live and the needs imposed by some treatments interfere directly in the health promotion process among such groups, and thus, result in greater vulnerability. In this context, the present study focused on patients with neurogenic bladder, who are submitted to a complex treatment process and require access to qualified professionals and developed technological and social resources ${ }^{(7-8)}$.

Patients with neurogenic bladder can present changes in micturition patterns in the urinary filling, storage, and emptying stages. In this context, among the main treatment options is the insertion of a clean intermittent urinary catheter. This is a safe method that allows the bladder to be periodically emptied at routine intervals, by introducing a catheter through the urethra. This technique is used frequently in the home setting and can be carried out either by patients or caregivers ${ }^{(7-8)}$.

Intermittent urinary catheters can cause significant changes in the activities of daily living of these individuals, as they stimulate urination and prevent signs and symptoms of urinary incontinence and urinary tract infection. This procedure also helps improve self-esteem, independence, and self-confidence, which are generally affected by feelings of shame, social restrictions, and difficulty adapting to treatment in daily activities ${ }^{(7,9-10)}$.
In this process, treatment incurs significant costs to patients and families. However, the Brazilian legislative system ensures that patients can afford expenses with medications, logistics, and professional health care. Through the social security system, workers and their families receive a benefit equal to a monthly minimum wage to replace the income of individuals who become unfit to work because of illness, disability, advanced age, death, involuntary unemployment, maternity, and imprisonment ${ }^{(11)}$.

Among the benefits offered to patients with neurogenic bladder, special mention goes to disability benefits or retirement due to disability provided by social security. The choice of benefit depends on the level of the debilitating disease, which can be either total or partial, and temporary or definitive, as set forth in the Social Security Benefits Law, Law no. 8.213/91 ${ }^{(12)}$.

Thus, even though social security recognizes the existence of disability due to the use of urinary catheters and does not allow beneficiaries to work, the aim of the present study was to demonstrate that these patients not only need the financial support provided by these benefits, but also need to be socially included in order to effectively exercise their rights.

\section{OBJECTIVE}

To identify the influence of social determinants of health on the life conditions of intermittent urinary catheter users.

\section{METHOD}

\section{Ethical aspects}

The present study was conducted after approval by the Research Ethics Committee of the Ribeirão Preto College of Nursing at University of São Paulo. Data were collected after informed consent forms were signed by patients or their legal guardians.

\section{Study design, location, and period}

This was a descriptive study ${ }^{(13)}$ developed in a urology outpatient clinic in the rehabilitation center of a university hospital in the state of São Paulo, Brazil. The facility is integrated into the Brazilian public health system and is a regional reference for other health units, receiving patients from other regions of the country. Data were collected between March 2012 and October 2015.

\section{Sample or population; inclusion criteria}

The sample was made up of patients with neurogenic bladder using clean intermittent urinary catheters, who were undergoing urological rehabilitation treatment at the studied unit, 18 years old or older, or, when younger than 18, accompanied by their parents or legal guardians. Data collection was aimed at patients who used clean intermittent urinary catheters. The study included 243 participants. 


\section{Study protocol}

Data were collected during a nursing appointment. Participants were interviewed using a semi-structured instrument already used at the service ${ }^{(14)}$. This instrument gathers sociodemographic patient data relative to social determinants of health, such as age, occupation, gender, state of origin, marital status, education level, employment status, benefits (disability retirement or social security disability benefit), household income in monthly minimum wages, and number of residents in the household, in addition to gathering the main characteristics of clean intermittent catheterization.

\section{Analysis of results}

The data were coded and double data entry was performed on an Excel spreadsheet, which was then exported and analyzed using the SPSS program (Statistical Package for the Social Sciences), version 19.0 (Windows). The results were discussed in light of the literature and according to the research objective using descriptive statistics, in terms of frequency and percentage.

\section{RESULTS}

In the present study, $243(100 \%)$ patients were interviewed. Table 1 presents the characteristics of these patients.

Table 2 describes the characteristics of participants in terms of education level, monthly income, and financial condition.

The SDH found in this study were associated with socioeconomic, demographic, and health aspects present in the interview instrument. Table 3 presents the variables (whether material is given, type of catheter used, and who performs the intermittent urinary catheterization) pertinent to the SDH that influence how patients carry out intermittent urinary catheterization.

Table 1 - Patient characteristics by gender, age, marital status, and origin

\begin{tabular}{lcc}
\hline Variables & $\mathbf{f}$ & $\mathbf{\%}$ \\
\hline Gender & & \\
$\quad$ Male & 151 & 62.1 \\
$\quad$ Female & 92 & 37.9 \\
Age & & \\
0-15 years old & 48 & 19.7 \\
16-64 years old & 176 & 72.5 \\
$\quad$ Over 65 years old & 19 & 7.8 \\
Marital status & & \\
$\quad$ Single & 141 & 58.0 \\
$\quad$ Married & 73 & 30.0 \\
$\quad$ Widowed & 8 & 3.3 \\
$\quad$ Divorced & 14 & 5.8 \\
Cohabiting & 7 & 2.9 \\
State of origin & & \\
$\quad$ São Paulo & 227 & 93.4 \\
$\quad$ Others (Goiás, Mato Grosso, and Minas Gerais) & 16 & 6.6 \\
\hline
\end{tabular}

Note: $f$ - absolute frequency; \% - percentage.
Table 2 - Patient characteristics according to education level, number of residents per family, household income, and financial situation

\begin{tabular}{lcc}
\hline Variables & $\mathbf{f}$ & $\%$ \\
\hline Education level & & \\
$\quad$ Illiterate & 35 & 14.4 \\
$\quad$ Elementary education & 120 & 49.4 \\
$\quad$ Secondary education & 70 & 28.8 \\
$\quad$ Tertiary education & 18 & 7.4 \\
No. of residents & & \\
1 & 23 & 9.5 \\
2 to 3 & 122 & 5.2 \\
4 to 6 & 91 & 37.4 \\
7 to 10 & 7 & 2.9 \\
Monthly household income & & \\
$<1$ Minimum wage* & 13 & 5.3 \\
1 Minimum wage & 61 & 25.1 \\
2 to 3 Minimum wages & 84 & 34.6 \\
3 to 4 Minimum wages & 73 & 30 \\
5 to 9 Minimum wages & 11 & 4.5 \\
$>$ 10 Minimum wages & 1 & 0.4 \\
Social security aspects & & \\
Retired & 102 & 42 \\
Beneficiary** & 81 & 33.4 \\
Employed & 19 & 7.7 \\
No benefit & 35 & 14.3 \\
Did not know & 6 & 2.6 \\
\hline
\end{tabular}

Note: $f$ - absolute frequency; $\%$ - percentage; * Value minimum wage $B R L$ 678,$00 ; * *$ Disability benefit.

Table 3 - Distribution of patients by variables related to the social determinants of health: receiving materials, type of catheter used, and who performs the intermittent urinary catheterization

\begin{tabular}{lcc}
\hline Variables & $\mathbf{f}$ & $\%$ \\
\hline $\begin{array}{l}\text { Material was given } \\
\text { Yes }\end{array}$ & 209 & 86.0 \\
No & 34 & 14.0 \\
$\quad$ & \\
Type of catheter & 219 & 90.1 \\
$\quad$ Polyethylene & 24 & 9.9 \\
$\quad$ Glass & & \\
Who performs procedure & 129 & 53.1 \\
$\quad$ Patient alone & 114 & 46.9 \\
$\quad$ With the help of the caregiver & & \\
\hline Note: $f$ - absolute frequency; \% - percentage. &
\end{tabular}

\section{DISCUSSION}

In the last five decades, the $\mathrm{WHO}$ and its members have been mobilized and have taken actions relative to the importance of SDH that affect the health conditions of people. In this direction, international government organizations have sought to encourage the definition of effective and decisive policies related to SDH. In Brazil, the Brazilian Commission on SDH 
has defined that these determinants are the social, economic, cultural, ethnic/racial, psychological, and behavioral factors that influence the occurrence of health problems and their risk factors among the population ${ }^{(15)}$.

The Brazilian Federal Constitution considers health as a right of all Brazilian citizens, which should be ensured by the State. Thus, individuals must be given all the conditions to be able to promote and/or recover health. The health/illness process is intricate and involves several factors, which leads to the population's difficulty in accessing their right to health ${ }^{(5,15)}$.

Studies about SDH among specific groups of patients contribute to the expansion of the concept of health, identifying the impact of social, behavioral, cultural, economic and psychological factors, which broadens the responsibility of the State. Not only must it ensure conditions to care for the health of the population as a whole, but more specifically for professionals who plan and deliver health care to meet the needs of specific groups of patients ${ }^{(11,15-18)}$. In this context, access to health services among groups is unequal, and systematic actions that promote equity can transform the health conditions of these populations and avoid the adverse effects of such inequity ${ }^{(18)}$.

The results of the present study are discussed from the perspective of carrying out an analysis of the sociodemographic values reflected on the participants' health and living conditions.

\section{Gender, marital status, and state of origin}

Most of the participants were men, which can be explained by the high incidence among this population of individuals who develop neurogenic bladder due to spinal cord injury ${ }^{(7)}$. Young men are more exposed to accidents and violence because of lifestyle choices, and usually need greater adaptations, especially in terms of locomotion. They also demand more help to access health services and support for other activities, such as leisure and relationships. In this direction, many of the patients in the sample did not have a partner (Table 1).

Furthermore, it is worth emphasizing that establishing a romantic relationship could have positive psychological impacts on the patient and treatment maintenance ${ }^{(16)}$. Several individuals choose not to engage in leisure and social activities because of inhibition related to their health condition, some because of urinary and fecal incontinence, or the use of diapers or urine collectors. These patients should be oriented about the care required for their treatment, so that social isolation is not encouraged.

In this context, the rehabilitation center is a reference in care for urinary catheter patients in the public health system, with patients coming from various different cities and states. The multidisciplinary team carries out interventions that promote patient independence and autonomy in their activities of daily living. However, more specialized centers must be created to meet the demand at the national level, thus avoiding the overcrowding of existing health units, which results in long patient waiting time and difficulty in carrying out treatment ${ }^{(14,16)}$.

Income, social security aspects, education level, and age

The data (Table 2) show that mean household income was low (between 2 and 3 minimum wages), which contrasts with the number of residents ( 4 to 6 people) per household, placing this population within a range of risk in terms of being able to meet their basic needs. It is also important to emphasize that when these patients retire or acquire disability benefits, they usually receive one minimum wage and are prohibited by law to carry out paid work lest they lose their benefits. This fact is even more relevant when considering the studied sample, of which $72.5 \%$ were considered to be economically active and could be encouraged to develop activities compatible with their health conditions, contributing to their household income and self-esteem.

The data point to the hypo-sufficiency that exists among this group, a reflection of the health inequities and the impact of $\mathrm{SDH}$, with a financial, political and psychological context and social barriers that such patients must face in their daily lives.

Low education levels, low household income per capita, and lack of employment can influence the quality of treatment maintenance. When faced with their new health condition and initiating treatment, patients must adapt to reorganize their lives, which involves expensive material resources and access to qualified health services ${ }^{(17)}$.

Lack of employment compromises individual income and also affects self-esteem and how patients are perceived by their families and society ${ }^{(10)}$. Of the interviewed patients, many received disability retirement or benefits, but could have developed work activities compatible with their health condition, complementing their income and nurturing independence and self-esteem, which emphasizes the influence of $\mathrm{SDH}$ factors in their living conditions. Thus, allowing economically active people to mitigate their difficulties associated with the disease through work is to ensure their constitutional right to full health and foster greater possibilities of equality to live a life with dignity, without physical, psychological and financial limitations.

As shown in Table 2, 14.3\% of patients reported not receiving any type of benefit, whether related to employment or social security. This inequity present in the area of health hinders the presence of these individuals in the labor market, creating dependence on other family members or even on health services to receive the care required by the disease ${ }^{(17-19)}$.

It is possible that patients may have been unaware of the type of benefit received and given an incorrect answer, as there are significant differences in terms of the characteristics and requirements that classify benefits into one legal type or another. Furthermore, there are different ways of calculating monthly income.

As shown in Table 1, there was a significant amount of children among urinary catheter patients, who are under Brazilian law that does not allow to work until 14 years of age. At 14 years old and older, youths can work as apprentices, entering the labor market in productive activities that can lead to a more promising future, in which they no longer are beneficiaries ${ }^{(12)}$.

Consequently, patients between zero and 15 years of age were completely financially dependent on their parents or legal guardians. In addition to the children, other patients also needed help with urinary catheterization, which means that other people had to enter into a routine to meet the needs of patients, which can incur more costs to the family or reduced 
income of another member of the family, who takes on the role of caregiver.

\section{Health conditions}

Many patients needed help performing the urinary catheterization, and not all were given the material to carry out the procedure and the medications they needed. There were discrepancies between norms to supply the materials for the procedure, which causes disparity among patients in terms of exercising their rights, because each municipality has the freedom to choose whether or not to ensure patients their right to have access to catheters through health services.

Among the municipalities that participated in the present study, material was made available free of cost for most patients (Table 3), as per the resolutions of the Pharmacy and Therapeutics Commission and the protocols of municipal Nursing Divisions, among others ${ }^{(14)}$. However, most patients still had to purchase catheters to carry out the procedures. In this context, the difference in exercising the user's rights to urinary catheterization is due to divergences in who receives the supplies for treatment. Patients are not given the material if in their residential area it is not supplied free of cost, through legal provisions. Another important aspect is the difficulty accessing the treatment location, for example, such as distance between the place of residence and treatment location, transportation, and costs.

Thus, when patients do not receive all the materials and resources required for urinary rehabilitation and when their family income is further reduced with expenses on equipment and materials, their right to health is compromised. In the Brazilian Federal Constitution, health is a right of citizens and duty of the State, which must provide individuals with the necessary conditions to promote and recover health ${ }^{(5)}$. However, within the scope of the national health system, each health unit is structured differently, in accordance with regional development levels; thus not every unit can provide patients with the necessary resources ${ }^{(14)}$.

It is always necessary to keep in mind that advocacy is one way to promote policies that can improve equity in health; however, it requires persistent awareness-raising efforts and an understanding of the social determinants of health ${ }^{(1)}$. Therefore, the construction of a more just and healthy society requires that advocacy efforts work together with the health sciences ${ }^{(19)}$.

One approach to human rights is based on the citizen responsibility and empowerment regarding self-care and to claim one's rights to health care and to participate in decision-making processes, harmonizing SDH with well-being. It is important to recognize that health policies based on the premises of human rights provide more comprehensive answers than those based solely on fragmented strategies. By giving attention to the health needs of marginalized and vulnerable populations, such policies are powerful tools for achieving positive outcomes ${ }^{(19)}$.

\section{Study limitations}

The findings of the present study are limited to a local population. Thus, it is necessary to expand this investigation to obtain a regional and national profile of the target population. Further studies in the area are needed to meet the needs of this population and identify irregularities and clinical, social and financial problems, which can contribute to promoting better treatment adherence and outcomes in the living conditions of neurogenic bladder patients using clean intermittent urinary catheterization.

\section{Contributions to the fields of nursing, health or public policy}

The study of SDH and how they interfere with the health conditions of a given social group is an important way of assessing the capacity of individuals to maintain their health condition. Furthermore, it promotes a global understanding of the meaning of health, providing greater conditions to develop health promotion strategies. Last, such research expands on the current concept of health and the understanding of the State's responsibility in implementing this social right in society.

To reach the goals that can change this scenario, a viable strategy includes training undergraduate students in health professions to address practical situations with vulnerable populations. Thus, the concept of SDH is better apprehended and students are better trained to develop a practice that reduces health inequities in work-related aspects, and to engage in systematic dialogue with decision and policy makers within the scope of the ministries of health.

Experiencing limitations imposed on groups of patients, such as the one in the present study, fosters and promotes the development of competencies of future professionals, both technically and conceptually. These professionals will have a broader understanding of their professional role and their responsibility of providing the health system with evidence, assessments, and examples of good practices related to $\mathrm{SDH}$.

It is also essential to invest in research and the generation of evidence, which is vital to monitoring inequalities, inequities and social injustice, as it provides decision and policy makers with indicators and measurements on which to base lines of actions in search of solutions and problem-solving capacity through successful programs and practices to protect vulnerable individuals.

The implementation of collaborative research networks can boost the capacity and sustainability of a system that can influence policies and translate knowledge into practice. This leads to partnerships among institutions and synergy to create innovative methodologies, establish new collective perspectives towards SDH and equity in health, thus meeting the needs of the population.

For nursing, knowledge about the influence of SDH in the lives of patients is essential, especially when constructing care plans for families. By understanding which patients are in better conditions to maintain health than others, nurses can better allocate their care resources. A study about the role of home care nurses reinforced the importance of the work of nurses in coordinating patient and family care plans, which requires that professionals be equipped with the necessary knowledge to develop this activity ${ }^{(20)}$. On understanding the relationship between $\mathrm{SDH}$ and social groups, nurses are can provide patients with an orientation about how to seek out their rights through legal devices. Moreover, this knowledge allows them to develop the competencies to propose and implement measures and changes in the health system of which they are part. 


\section{CONCLUSION}

The SDH found in this study were related to socioeconomic, demographic and health factors. The findings indicate a complex relationship between such $\mathrm{SDH}$ and the living conditions of neurogenic bladder patients using clean intermittent urinary catheters. However, it was possible to identify that these SDH influence the living conditions of these patients, frequently hindering effective and adequate treatment maintenance.

The study presents several possibilities that should be discussed in the light of further research about SDH and vulnerable social groups, with contributions to the area of nursing, health or public policies.

\section{REFERENCES}

1. World Health Organization-WHO. WHOQOL: Measuring Quality of Life. WHO/MSA/MNH/PSF/97.4. Geneva: WHO; 1997.

2. Bhattacharya S. The local bases of global public health: complexities and opportunities. Bull World Health Organ [Internet]. 2008 [cited 2016 Apr 13];86(3):163-3. Available from: https://scielosp.org/pdf/bwho/2008.v86n3/163-163/en

3. Östlin P, Schrecker T, Sadana R, Bonnefoy J, Gilson L, Hertzman C, et al. Priorities for research on equity and health: towards an equity-focused health research agenda. PLoS Med [Internet]. 2011;8(11):e1001115. Available from: https://www.ncbi.nlm.nih.gov/ pmc/articles/PMC3206017/pdf/pmed.1001115.pdf

4. Kickbusch I, Lister G, Told M, Drager N. Global Health Diplomacy: concepts, issues, actors, instruments, fora and cases. New York: Springer; 2013.

5. Brasil. Constituição 1988. Constituição da República Federativa do Brasil. Brasília (DF): Senado; 1988.

6. Baptista TWF, Machado CV, Lima LD. State responsibility and right to health in Brazil: a balance of the Branches' actions. Ciênc Saúde Colet[Internet]. 2009 [cited 2016 May 09];14(3):829-39. Available from: http://www.scielo.br/pdf/csc/v14n3/en_18.pdf

7. Nogueira PC, Rabeh SAN, Caliri MHL, Dantas RAS, Haas VJ. Burden of care and its impact on health-related quality of life of caregivers of individuals with spinal cord injury. Rev Latino-Am Enfermagem [Internet]. 2012[cited 2015 Jun 21];20(6):1048-56. Available from: http://dx.doi.org/10.1590/S0104-11692012000600006

8. Woodward S, Steggal M, Tinhunu J. Clean intermittent self-catheterisation: improving quality of life. Br J Nurs [Internet]. 2013[cited 2015 Jun 21];22(9):S22-5. Available from: https://www.ncbi.nlm.nih.gov/pubmed/23752575

9. Center for Disease Control and Prevention-CDC. Guideline for prevention of catheter-associated urinary tract infections. Atlanta: CDC; 2009.

10. Vahr S, Cobussen-Boekhorst H, Eikenboom J, Geng V, Holroyd S, Lester M, et al. Catheterisation: urethral intermittent in adults. The Netherlands: European Association of Urology Nurses; 2013.

11. Brasil. Ministério da Saúde. Diretrizes de Atenção à Pessoa com Lesão Medular [Internet]. Brasília (DF): Ministério da Saúde; 2013. Available from: http://bvsms.saude.gov.br/bvs/publicacoes/diretrizes_atencao_pessoa_lesao_medular.pdf

12. Brasil. Lei n. 8.213 de 24 de julho de 1991. Dispõe sobre os Planos de Benefícios da Previdência Social e dá outras providências. Brasília, DF: Senado; 1991. Available from: http://www.planalto.gov.br/ccivil_03/Leis/L8213cons.htm

13. Polit DF, Beck CT. Fundamentos de Pesquisa em Enfermagem. $7^{\text {th }}$ ed. Porto Alegre: Artmed Editora; 2011.

14. Mazzo A, Souza Jr V, Jorge BM, Nassif A, Biaziolo CFB, Cassini MF, et al. Intermittent urethral catheterization- descriptive study at a Brazilian service. Appl Nurs Res [Internet]. 2014[cited 2015 Jun 21];27(3):170-4. Available from: https://www.ncbi.nlm.nih. gov/pubmed/24559718

15. Brasil. Portaria $n^{\circ} 2.446$ de 11 de novembro de 2014. Redefine a Política Nacional de Promoção da Saúde-PNPS. Brasília, DF: Senado; 2014. Available from: http://bvsms.saude.gov.br/bvs/saudelegis/gm/2014/prt2446_11_11_2014.html

16. Bolinger R, Engberg S. Barriers, complications, adherence, and self-reported quality of life for people using clean intermittent catheterization. J Wound Ostomy Continence Nurs [Internet]. 2013[cited 2015 Jun 21];40(1):83-9. Available from: http://dx.doi. org/10.1097/WON.0b013e3182750117

17. Cunha M, Santos E, Andrade A, Jesus R, Aguiar C, Marques F, et al. Effectiveness of cleaning or disinfecting the urinary meatus before urinary catheterization: a systematic review. Rev Esc Enferm USP [Internet]. 2013[cited 2015 Jun 21];47(6):1410-6. Available from: http://dx.doi.org/10.1590/S0080-623420130000600023

18. Farrer L, Marinetti C, Cavaco YK, Costongs C. Advocacy for Health Equity: a synthesis review. Milbank Q[Internet]. 2015[cited 2014 Jan 18];93(2):392-437. Available from: https://www.ncbi.nlm.nih.gov/pmc/articles/PMC4462882/pdf/milq0093-0392.pdf

19. Sanghera J, Gentile L, Guerras-Delgado I, O'Hanlon L, Barragues A, Hinton RL, et al. Human rights in the new Global Strategy. BMJ [Internet]. 2015 [cited 2016 Jul 31];351:h4184. Available from: http://www.bmj.com/content/bmj/351/bmj.h4184.full.pdf

20. Andrade AM, Silva KL, Seixas CT, Braga PP. Nursing practice in home care: an integrative literature review. Rev Bras Enferm [Internet]. 2017[cited 2017 Jul 25];70(1):210-9. Available from: http://dx.doi.org/10.1590/0034-7167-2016-0214 